\title{
NEW FROMOXFORD
}

\section{NEUROPSYCHOLOGICAL ASSESSMENT \\ Third Edition \\ Muriel Deutsen Lezak}

"This is-and will remain-a very important and central book in clinical neuropsychology. No other current book dealing with the practice of adult clinical neuropsycholog has as much to offer.... A truly impressive achievement." - Journal of Clinical Neuropsychology (on the 2 nd ed.) 19951056 pp.; 110 illus. $\$ 65.00$

\section{Forthcoming}

\section{TRAUMATIC HEAD INJURY IN}

CHILDREN

Edtted by Sarah H. Broman and Mary Ellen Michel

Presenting a broad review of traumatic brain injury in children, this book covers its pathophysiology, treatment and outcome.

September 1995256 pp.; 36 illus. $\$ 39.95$

Forthcoming

\section{DEVELOPMENTAL}

\section{NEUROPSYCHIATRY}

VOLUME 1: FUNDAMENTALS

JAMES C. HARRIS

This volume provides the fundamental background information needed for understanding the neurodevelopmental disorders.

August 1995256 pp.; 34 illus. $\$ 45.00$

Fortheoming

\section{DEVELOPMENTAL}

\section{NEUROPSYCHIATRY}

VOLUME 2: ASSESSMENT, DIAGNOSIS, AND TREATMENT OF DEVELOPMENTAL DISORDERS

JAMES C. HARRIS

This book offers a thorough review of the assessment. diagnosis and treatment of neurodevelopmental disorders. The two volumes together synthesize recent developments in neurobiology, cognitive neuroscience. child development and developmental psychopathology.

August 1995544 pp.; 18 illus. $\$ 75.00$

\section{CONTRIBUTIONS TO}

\section{NEUROPSYCHOLOGICAL}

\section{ASSESSMENT}

\section{A Clinical Manual}

Second Edition

arthur L Benton, Abigall B. Sivan, Kerry des. Hamsher. NILS R. VARNEY AND OTFRIED SPREEN

"Not just another battery to use indiscriminately.. but a precious kit of diagnostic tools among which the accomplished neuropsychologist will select those suited to answer...specific questions." - Contex (on the Ist ed.) 1994176 pp.; 13 illus. paper $\$ 24.95$

\section{NEUROPSYCHOLOGY OF HIV INFECTION}

igor Grant and Alex Martin

"The neuroimaging examples presented are outsuanding...The references are extensive and as up-to-date as possible.....An excellent review of current neuropsychologiCal studies in this new and often controversial arez."

-Eileen Martin, PhD, Univ. of Illinois at Chicago College of Medicine, Doody's Journol

1994402 pp.; 59 b\&w Illus, 2 plates color $\$ 59.50$

\section{Clock DRAWING}

A NEUROPSYCHOLOGICAL ANALYSIS

MorRIS FreEDMAN, LarRY LEACH, EDITH KaPUAN,

GORDON WINOCUR AND KENNETH I. SHULMAN

Written by a multi-disciplinary team of experts in neurobehavior, this concise, well-illustrated book provides long-awaited normative daca on clock drawing from ages 20 to 90 years.

1994192 pp.; 56 illus. $\$ 35.00$
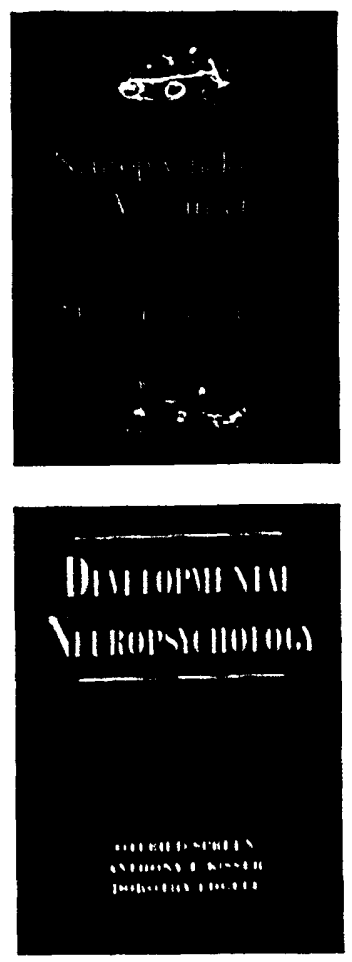

Contributions to Neuropsychological Assessment
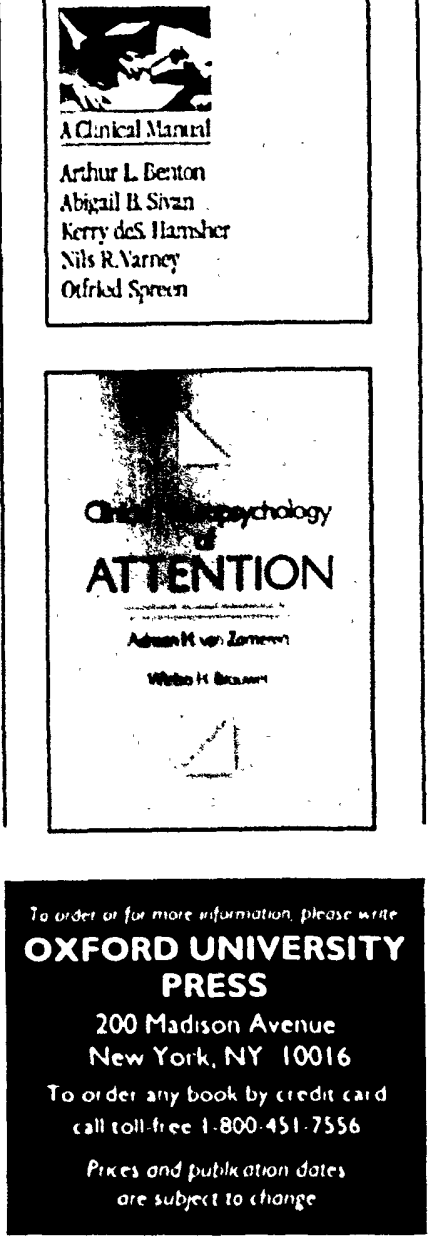

Forthcoming

PEDIATRIC NEUROPSYCHOLOGY IN A MEDICAL SETTING

IDA SUE BARON, EILEEN B. Fennell and KrTJa K. S. Voeller This book provides a basis for understanding and evaluating the impact of medical conditions on the developing brain and offers much practical clinical information. July 1995164 pp.; 8 illus. $\$ 55.00$

\section{DEVELOPMENTAL}

NEUROPSYCHOLOGY

Otfried SPREEN, ANTHONY H. RISSER AND DOROTHY EDGELl "Brilliant clarity.... An important text; it is authoritatively and exceptionally clearly written, and well integrated with key facts." - Book Reviews in the Neurosciences (on the pre. vious edition)

1995688 pp.; 89 illus. paper $\$ 39.95 /$ cloth $\$ 65.00$

\section{HUMAN BRAIN ANATOMY IN COMPUTERIZED IMAGES Hanna Damasio}

"The most painstaking and thorough as well as sophisticated and timely computerized images depicting human brain anatomy."-Deepak N. Pandya, M.D., Boston University

School of Medicine

1995320 pp.; 262 illus. $\$ 85.00$

\section{Forthcoming}

\section{CATASTROPHIC BRAIN INJURY}

EDITED BY HARVEY S. LEVIN, ARTHUR L. BENTON, J. Paul Muizeunar and Howard M. EIsenbero Integrating clinical and research findings on catastrophic brain injury, this work addresses the pathophysiology, definition, epidemiology and outcome of severe closed head injuries.

November 1995288 pp.; 14 illus. $\$ 39.95$

\section{NEUROSURGERY}

\section{AN INTRODUCTORY TEXT}

Peter Mclaren Buck and Eugene Rossitch, Jr.

A concise introduction to neurosurgery, this text emphasizes the diagnosis and management of neurosurgical dis. orders.

1995248 pp.; 20 illus. paper $\$ 24.951$ cloth $\$ 49.95$

\section{Clinical Neurology of Aging} Second Edition

Eotted by Martin L Albert and janice E. Knoefel

"Outstanding and most useful....Drs. Albert and Knoefel deserve our thanks and congratulations for having made available this vast amount of information." -JAMA 1994728 pp.; 120 illus. \$125.00

\section{CLINICAL NEUROPSYCHOLOGy of} ATTENTION

ADRIAAN H. VAN ZOMEREN AND WIEBO H. BROUWER "An eminently clinically oriented book.... Very well-written.... This excellent book is warmly recommended." Elecaroencephalogrophy and Clinical Neurophysiology 1994264 pp.; 39 illus. $\$ 35.00$

\section{COGNITIVE ASSESSMENT FOR CLINICIANS \\ JOHN R. HODGES}

"A concise, well-written introduction to cognitive assess. ment at the bedside....Practical and useful."-Daniel B. Hier, MD. Univ. of Illinois at Chicago College of Medicine. Doody's Joumal

1994256 pp.; 34 Illus. paper $\$ 27.95$

\section{CLINICAL NEUROPSYCHOLOGY \\ Third Edicion}

EDITED BY KENNETH HEIIMAN AND EDWARD VALENSTEIN

"Its great strength lies in its completeness and authorita. tive coverage. Several of the chapters may be regarded as definitive." $-\mathrm{NE} M$

1993752 pp.; 47 illus. $\$ 65.00$ 


\section{CAMBRIDGE - Exploring Neuropsychology and Related Fields}

\section{New edition.. \\ Scientific Style and \\ Format}

The CBE Manual for Authors, Editors, and Publishers

Sixth Edition

\section{Edward J. Huth}

"There is no other book like this for the scientific and technological community. It should be the major desk reference for anyone writing a scientific article or book.... Highly recommended..."

-Booklist/Reference Books Bulletin $1994782 \mathrm{pp}$.

47154-0 Hardback $\$ 34.95$

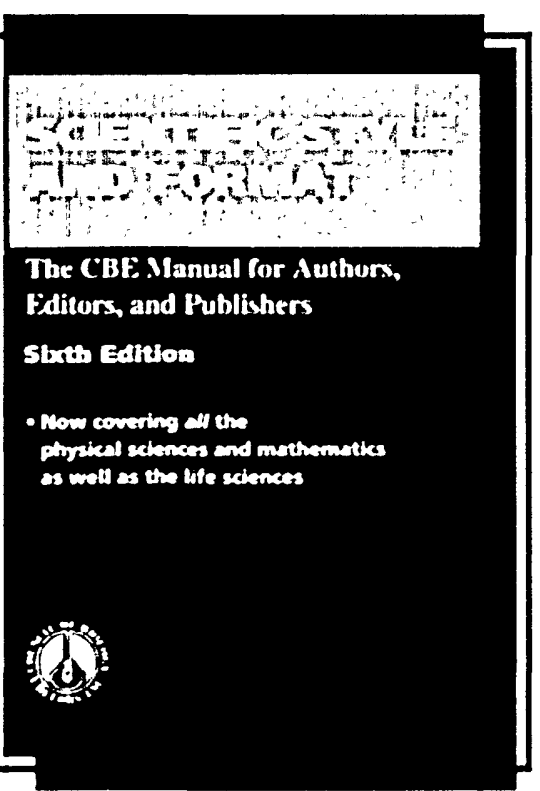

\section{Psychosocial Processes}

\section{and Health}

A Reader

\section{Andrew Steptoe and} Jane Wardle, Editors

Assembles the most important articles regarding psychosocial processes and health of the past thirty years. The thirtyone articles are grouped around themes such as "Life stress, social support and health," "Psychophysiological processes in diseases," and "Behavioral interventions in medicine."

$1995537 \mathrm{pp}$.

$\begin{array}{lll}41610-8 & \text { Hardback } & \$ 94.95 \\ 42618-9 & \text { Paperback } & \$ 39.95\end{array}$

\section{Functional Psychiatric} Disorders of the Elderly Edmond Chiu and

\section{David Ames, Editors}

Provides a comprehensive reference and thorough practical guide to all the psychiatric disorders of the elderly not known to be caused by organic disease by covering psychiatry neuroses, affective disorders, substance abuse, psychosexual disorders, schizophrenia, epidemiology, and treatment methods.

$1994650 \mathrm{pp}$.

43160-3 Hardback $\$ 100.00$

\section{Stress, Risk, and Resilience in Children and Adolescents}

Processes, Mechanisms, and Interventions

Robert J. Haggerty,

Lonnie R. Sherrod,

Norman Garmezy, and

Michael Rutter, Editors

Recognizes the complexity of the developmental processes that influences coping and resilience and the importance of sociocultural factors.

1994441 pp.

44146-3 Hardback $\$ 49.95$

Describes the modes of assessment, behavioral expressions, and genetic and psychobiological bases that accompany the tendency to seek novel, varied, complex, and intense sensations and experiences and the willingness to take these risks for the sake of such experience.

$1994477 \mathrm{pp}$.

43200-6 Hardback $\$ 64.95$

43770-9 Paperback $\$ 32.95$

\section{Behavioral Expressions and Biosocial Bases of Sensation Seeking Marvin Zuckerman}

Causal Mechanisms of Behavioural Development

Jerry A. Hogan and

Johan J. Bolhuis, Editors

Discusses all the significant conceptual and empirical advances in the study of behavioral development. It features the approach that learning is considered to be one process contributing to the development of the individual from conception to death.

$1994435 \mathrm{pp}$.

43241-3 Hardback \$54.95

\section{Treatment of Anxiety Disorders}

A Clinician's Guide and Patient Manuals Gavin Andrews, Rocco Crino, Caroline Hunt, Lisa Lampe, and Andrew Page

Treatment of Anxiety Disorders provides clinicians with an authoritative review of the epidemiology, etiology, and evaluation of anxiety disorders. Its unique and most useful feature is that each section contains a "Patient Treatment Manual" for conducting a comprehensive and effective cognitive behavioral program with each patient being treated for common anxiety disorders. The set of five manuals may be purchased separately.

$1995408 \mathrm{pp}$.

46521-4 Hardback \$74.95

46927.9 Paperback $\$ 34.95$

46958.9 Paperback $\$ 19.95$ (manuals)

\section{Dementia and Normal}

Aging

Felicia A. Huppert,

Carol Brayne, and

D. W. O'Connor, Editors

Reviews the latest scientific research and seeks to establish whether dementia, particularly Alzheimer's disease, is distinct from the normal aging process or on a continuum with normal aging. $1994586 \mathrm{pp}$.

41393-1 Hardback

$\$ 89.95$
Ardilable in besehstores or from
CAMBRIDGE UNIVERSITY PRESS
40 West 20th Street, New York, NY 10011-4211 Call toll-free 800-872-7423.

Master(iard/VISA accepted. Prices subject io change. 


\section{Instructions for Contributors}

\section{Alms and Scope}

JINS weicomes scholarly contributions broadly reflecting the interests of all areas of neuropsychology. Coverage will include, but is not limited to, topies in adult neuropsychology, child neuropsychology, developmental neuropsychology, disorders of speech and language, and the interfaces of neuropsychology with related areas such as behavioral neurology, neuropsychiatry, neuroimaging and electrophysiology. Book Reviews will also be published.

Neuropsychological topics include theoretical considerations such as the development of cognitive processes, and brain-behavior relationships. Submissions are also encouraged that employ neuropsychological methods as either independent or outcome variables to illuminate the processes of various neurological, medical, and psychiatric disorders. The focus of the work may be primarily experimental, more applied or clinical. The key requirements are that it be original, creative, and of high quality.

To assure maximum nexibility and to promote diverse mechanisms of scholarly communication, it is intended to offer at least the following formats in addition to regulas research articles: Rapid Communications $u$ hich should be brief and are intended for "fast-breaking" new work u hich does not yet justify a full length article; Case Studies that report interesting individual cases; Crition Reviews which should be thoughtful considerations of topies of importance to neuropsychologists; $U$ pdates intended to provide an educational exposition of cognate fields, e.s. functional brain imaging, neuroepidemiology, ethical issues, etc; Symposia consisting of several research articles on a thematically linked area; Diologues publishing arguments in a point-counterpoint form with two or more authors taking different positions on controversial issues in neuropsychology: and Letters to the Editor which should briefly report on observations or respond to recent aricles in JINS.

Critical Reviews, Updates, Symposia and Dialogues may be invited by the Department Editor responsible, or may be proposed by authors. Such proposals should be discussed with the Editor-in-Chief or the appropriate Department Editor before submission.

\section{Originality and Copyright}

To be considered for publication in JINS, a manuscript cannol have been published previously, nor can it be under review for publication elseu here. Papers with multiple authors are reviewed with the assumption that all authors have approved the submitted manuscrip and concur with its submission to JINS. A Copyright Transfer Agreement, with certain specified rights reserved by the au. thor, must be signed and returned to the Editor by senior authors of accepted manuscripts, prior to publication. This is necessary for the wide distribution of research findings. and the protection of both author and the society under conyright law.

\section{Manuscript Submission and Review}

An original and four complete copies including figures and illustrations should be sent to:

\section{Igor Grant, MD}

\section{Editor-in-Chief: JIN'S}

Denartment of P'sychiatry

Clinical Sciences Building, Room 249

University of California, San Diego

9500 Gilman Drive

l.a Jolla, CA 92093-0680

$\begin{array}{ll}\text { Phone: } & (619) \$ 34-4306 \\ \text { Fax: } & (619) \$ 52-4318 \\ \text { E-mail: } & \text { jins }(6 \text { ucsd.edu }\end{array}$

In a cover letict, the author should indicate the categony under which a manuscript is submitted and should identify the corresponding author including phone number, fax numbet and electronic mail address (if available).
The Editor-in-Chief will acknow ledge receipt of the manuscript, provide it with a manuscript reference number, and assign it for review to an Associate or Department Editor and at least two other reviewers. Every effort will be made to provide the author with a review within 10 weeks of manuscript assignment. Rapid Communications and Letters 10 the Editor will be reviewed within 6 weeks. If the Editor requests that revisions be made to a manuseript before publication, a maximum of 4 months will be al. lowed for preparation of the revision, except in unusual circumstances.

\section{Mlanuscript Length}

Regular Rescarch Articles-maximum of 5,000 words and a 200 u ord abstract (approximately 20 double-spaced manuscript pages, not including references and tables) but exceptions uill be considered for unusually large or complex studies. Rapid Communications-maximum 2,500 words and a 150 word abstract, approximately 10 double spaced manuseript pages, with a maximum of two tables and/or two figures. Rapid Communications should list no more than 20 references. Cose Studies - for interesting cases, maximum 2,500 words with an informative litera. ture review and an abstract not exceeding 150 words. Let ters to the Editor - maximum 500 words with up to five references, one table or one figure.

\section{Manuscript Preparation and Style}

The entire manuscript should be typed double-spaced throughout on $8.12^{*} \times 11^{\circ}$ or A4 paper, Unless otherwise specified, the guideline for preparation of manuscripts is the Publication Mtanual of the American Psychological As sociation (Ath edition). This may be ordered from: APA Order Dept., 750 Ist St. NE, Washington DC 20002-4242. USA.

Pages should be numberal sequentially beginning with the Title Page. The Title Page should contain the full title of the manuscript, the full names and affiliations of all authors, a contact address with telephone and fax num. bers, acknou led ements and support, and the name and address for requests for reprints. At the top right provide also a running headline (shortened title) of up to forty-five characters preceded by the lead author's last name. Example: Smith-Implicit Memory in Parkinson's. This running headline should be repeated at the top right of every fol. louing page.

The Abstract and Kejwords Page (page 2) should include a brief satement of the problem. the method, the key findings, and the conclusions. For Case Studies there should be a briel summary of the case and its relevance to the existing literature. A list of three or four hey words or terms should also be included.

The full text of the manuseript should begin on page 3. For scientific articles, including regular Research Articles and Rapid Communications, the format would include an In. troduction, Method, Results, and Discussion. This should be followed by References, Tables, Figures, and Figure Legends printed on a separate sheet.

The use of abbreviations, except those that are widely used, is strongly discouraged. They should be used only if they contribute to tetter comprehension of the manuseript. Acronyms should be spelled out at first mention. Metric system (SI) units should be used.

\section{Frures}

High quality laser-printed copies or photocopies are accepiable. Figures should be numbered consecutively as they apoxar in the text. Mlark each figure with the first au. thor's name, the figure number and the orientation on the reverse of the originals and copies. Any indication of features of special interest should also be included. Figures should be dran n or composed on computer to about twice their intended final size and authors should do their bes to construct figures with notation and data points of suf ficient size to permit legible photoreduction to one column of a two-column format. As a guide, no character should be smaller than $1 \mathrm{~mm}$ wide following reduction.

Color figures can be accepted. However, the extra costs of printing these figures must be paid by the author.

\section{References}

References should be in American Psychological Association style (see Manuscript Preparation and Style ahove).

Text references should be cited as follows: "The findings duplicated the results of an carlier study (Broun \& Greene 1991)," or "The method used was an enhancement of Bell and Tower's (1973) and Jones et al.'s (1977). ... If multiple works by Jones et al. (1977) are cited, use a, b, c, in the order these appear in the text. Multiple references should be cited alphabetically: "Previous studies (Adams et al., 1980; Davies and Engler, 1985; Watson, 1987)....." References cited in the text with three or more authors should state et al. even at first mention. Reference entries should be alphabetically listed in the reference section with all authors being cited. Examples of the APA reference style are as follow's:

Scientific Article:

Heaton, R.K., Grant, I., Anthony, W.Z. \& Lehman, R.A.W. (1981). A comparison of clinical and automated interpretation of the Halstead-Reitan Battery. Journol of Clinical Neuropsychology, 3, 121.141.

Book:

Russel, E.W., Neuringer, C., \& Goldstein, G. (1970). Assessment of brain damage: $A$ neuropsychological key approach. New York: Wiley.

\section{Chapter in Book:}

Reitan, R.MI. (1966). A research program on the psychological effects of brain lesions in human beings. In N.R. Ellis (Ed.), International Review of Rescarch in Afental Retardation, Vol. I (pp. 153-218). New York: Academic Press.

\section{Report at a Scientific Meeting:}

Berman, K.F., ZCC, R.F. \& Weinberger, D.R. (1989, May). Frontal cortical dysfunction in schizophrenta. Symposia presentation, American Psychiatric Association, Washington, DC.

Manual. Diagnostic Scheme, etc.:

American Psychiatric Association (1994). Diagnostic and Statistical M tanual of Mtental Disonders (th ed.). WashingIon, DC: American Psychiatric Association Press.

\section{Manuscript Disk}

When a manuscript has been accepted for publication, the authors are requested 10 submit a disk version of their manuscript along with two hard copies. The disk should be labeled with the manuscript number, the author's name and the original word-processing file. It should be noted that the disk file will be considered the final version of the manuscript.

Proofs

The publisher reserves the right to copyedit manuscripts. The corresponding author will receive page proofs for $\mathrm{fi}$. nal proofreading. These should be cheched and returned within 2 days of receipt. The publisher reserves the right to charge authors for excessive correction of nontypograph. ical errors.

\section{Orfprints}

The corresponding author will reccive 25 free offprints. Additional offprints must be ordered when page proofs are teturned. Price lists and order forms will be sent with page proofs. 


\section{Journal of the \\ International Neuropsychological Society}

Volume 1

Number 3

May 1995

\section{RESEARCH ARTICLES}

231

The HNRC 500-Neuropsychology of HIV Infection at Different Disease Stages

Detection of Dementia of the Alzheimer Type in a

Population-Based Sample: Neuropsychological Test Performance

261 Evidence of Altered Dominance in Children with Congenital Spastic Hemiplegia

271 The Biasing Effect of Verbal Labels on Memory for Ambiguous Figures in Patients with Progressive Dementia

281 Sensory-and Memory-Mediated Olfactory Dysfunction in Huntington's Disease

291 Mood Disturbance Versus Other Symptons of Depression in Multiple Sclerosis

297 Semantic Network Abnormality Predicts Rate of Cognitive Decline in Patients with Probable Alzheimer's Disease

\section{CRITICAL REVIEW}

304 Neuropsychological Studies of Asymptomatic Human Immunodeficiency Virus-Type-1 Infected Individuals
R.K. Heaton, I. Grant, N. Butters, D.A. White, D. Kirson, J.H. Atkinson, J.A. McCutchan, M.J. Taylor, M.D. Kelly, R.J. Ellis, T. Wolfson, R. Velin, T.D. Marcotte, J.R. Hesselink, T.L. Jernigan, J. Chandler, M. Wallace, I. Abramson, and The HNRC Group

D.A. Cahn, D.P. Salmon, N. Butters, W.C. Wiederholt, J. Corey-Bloom, S.L. Edelstein, and E. Barrett-Connor

M. Korkman and L. von Wendt

A.L. Ostergaard, W.C. Heindel, and J.S. Paulsen

S. Nordin, C. Murphy, and J.S. Paulsen

D.L. Nyenhuis, S.M. Rao, J.M. Zajecka, T. Luchetta, L. Bernardin, and D.C. Garron

A.S. Chan, D.P. Salmon, N. Butters, and S.A. Johnson

D.A. White, R.K. Heaton, A.U. Monsch, and The HNRC Group 